\title{
PAULO FREIRE E A LUTA POPULAR: ENTRE O DIÁLOGO E A VIOLÊNCIA REVOLUCIONÁRIA
}

DOI: $10.48075 /$ RI.V24I2.26628

Willian Grecillo dos Santos ${ }^{1}$

RESUMO: Este ensaio tem como objetivo a sistematização e discussão das elaborações teóricas de Paulo Freire acerca da categoria dialogicidade. O diálogo, no interior da pedagogia Freireana, é alicerce fundamental para a efetivação da proposta pedagógica do educador pernambucano, fazendo com que seu estudo sistemático seja uma necessidade primária para o campo teórico Freireano e para aqueles educadores dispostos a colaborar com a transformação social. Em geral, há uma compreensão problemática acerca da lógica dialógica proposta por Freire, tanto no universo acadêmico como fora dele. Uma forma rasa que concebe o diálogo enquanto uma manifestação verbal observada nas relações entre sujeitos e que se alinha a um discurso pregador de uma suposta tolerância absoluta. Por vezes, não poucas, essa concepção rasa de diálogo estampa a figura de Paulo Freire em uma narrativa de não violência que, em profundidade, busca cessar e desmobilizar as organizações populares que se desenvolvem movimentadas por uma práxis revolucionária. Em sua obra Pedagogia do oprimido, Freire não tenta, de forma alguma, esconder a essência revolucionária de sua proposta pedagógica, salientando as relações entre sua categoria dialogicidade e a violência intrínseca dos processos de libertação das classes populares. Nessa proposta pedagógica, há uma descrição profunda acerca da impossibilidade da inauguração da violência no mundo pela ação libertadora daqueles que têm sua vocação ontológica de ser mais negada. Portanto, não há qualquer tipo de contradição na relação entre uma concepção dialógica de estar no e com o mundo e uma práxis revolucionária corajosa, honesta e amorosa.

Palavras-chave: Paulo Freire; diálogo; revolução.

\section{PAULO FREIRE AND THE POPULAR STRUGGLE: BETWEEN DIALOGUE AND REVOLUTIONARY VIOLENCE}

ABSTRACT: This essay aims to systematize and discuss Paulo Freire's theoretical elaborations on the category of dialogicity. Dialogue, within Freirean pedagogy, is a fundamental foundation for the effectiveness of the pedagogical proposal of the educator from Pernambuco, making its systematic study a primary need for the Freirean theoretical field and for those educators willing to collaborate with social transformation. In general, there is a problematic understanding about the dialogical logic

\footnotetext{
${ }^{1}$ Licenciado em Física pela Universidade Federal de Santa Maria e mestrando do Programa de Pós-graduação em Educação Científica e Tecnológica da Universidade Federal de Santa Catarina. E-mail willian.grecillo89@gmail.com
} 
proposed by Freire, both in the academic universe and outside it. A shallow form that conceives the dialogue as a verbal manifestation observed in the relations between subjects and that is aligned with a discourse that preaches a supposed absolute tolerance. Sometimes, not a few, this shallow conception of dialogue prints the figure of Paulo Freire in a narrative of non-violence that, in depth, seeks to cease and demobilize popular organizations that are developed by a revolutionary praxis. In his work Pedagogy of the Oppressed, Freire does not attempt, in any way, to hide the revolutionary essence of his pedagogical proposal, emphasizing the relationships between his category of dialogicity and the intrinsic violence of the liberation processes of the popular classes. In this pedagogical proposal, there is a profound description about the impossibility of the inauguration of violence in the world due to the liberating action of those who have their ontological vocation to be more denied. Therefore, there is no contradiction in the relationship between a dialogical conception of being in and with the world and a courageous, honest and loving revolutionary praxis.

Key Words: Paulo Freire; dialogue; revolution.

"O alicerce fundamental de nossa obra é a juventude: depositamos nossa esperança nela e preparamo-la para tomar a bandeira de nossas mãos." Comandante Ernesto Che Guevara, O socialismo e o homem em Cuba, 1959.

\section{INTRODUÇÃO}

Sempre que entramos em momentos de aprofundamento das convulsões sociais, principalmente nos períodos de crises prolongadas do modo de produção capitalista, o discurso hegemônico na mídia e de representantes políticos da ordem é o do "diálogo". Há um consenso enraizado de que a revolta dos oprimidos é justificada, porém, a ação deve ser "dialógica", sem violência. Todavia, os prejuízos materiais acumulados durante essas revoltas são sempre contabilizados em vândalos, os quais perderam a razão de ser por responderem com violência a violência estrutural do sistema.

Ainda, não é incomum o nome de Paulo Freire surgir incorporado a esse discurso que "implora" pelo diálogo, justificando que este desenvolveu sua teoria e prática de forma alicerçada na tolerância e na dialogicidade. Porém, o educador e intelectual pernambucano desenvolveu sua filosofia pedagógica com profundidade e complexidade consideráveis, bem como a categoria dialogicidade. Portanto, esse discurso raso, que clama pelo diálogo a 
qualquer custo e em qualquer situação não é o suficiente para caracterizar o que a teoria Freireana ${ }^{2}$ compreende enquanto diálogo.

Para construir tal separação na polissemia que se constitui na conceituação em torno do termo "diálogo" e expor a contradição nesse tipo de narrativa, é importante reconhecer de onde Freire busca suas inspirações e referências que guiaram suas elaborações teóricas e práticas. É sabido que Freire se inspira em uma diversidade de referências para construir seu pensamento pedagógico. Michels e Volpato (2011) e Lourenço e Mendonça (2018) argumentam que Freire se desenvolve a partir de matrizes fenomenológicas, tendo como principal referência do campo o filósofo Edmund Husserl. Já Mantovani (2011) busca, a partir de referências ao pensamento de Hegel na obra Pedagogia do Oprimido, aproximar a pedagogia Freireana do sistema hegeliano, tendo como foco as bases lógicas da dialética. Ainda, Michels e Volpato (2011) e Freitas e Freitas (2013) destacam a profunda aproximação do autor em relação ao marxismo, a partir de suas ideias acerca do que seria práxis, a essência revolucionária de seu sistema teórico e o ponto de partida de todo o processo de ação e reflexão de sua proposta: a concretude da vida social e histórica dos sujeitos em situação de opressão, em uma concepção dialética. Nesse sentido, Silva $(2004 ; 2007)$ e Madureira (2019) realizam uma leitura marxista da obra Freireana a partir de suas concepções de "homem", trabalho, prática social, práxis e alinhamento ao projeto revolucionário que se direciona a uma estruturação comunista da sociedade.

Olhando mais atentamente para a obra Pedagogia do Oprimido é possível reconhecer referências estruturais do ensaio teórico que ali está exposto, como: Karl Marx, Friedrich Engels, Vladimir Lenin, Antonio Gramsci, Mao Zedong, Rosa Luxemburgo, Frantz Fanon, Louis Althusser, Ernesto Che Guevara, György Lukács e Álvaro Vieira Pinto. Essas referências são, indiscutivelmente, oriundas do campo ético-crítico e possuem como método basilar de suas construções o materialismo histórico e dialético ${ }^{3}$. Assim, Freire toma como ponto de partida uma concepção materialista e dialética acerca do real, desenvolvendo um olhar crítico,

\footnotetext{
2 Em contexto acadêmico, temos uma característica variação na denominação deste campo entre "Freireano" e "Freiriano". De acordo com regras gramaticais, o termo "Freiriano" seria mais aconselhável em relação ao antropônimo "Freire", porém, em uma breve busca pelas duas variações do termo no Banco de Teses e Dissertações (BDTD) e no Catálogo de Teses e Dissertações da CAPES evidencia como o termo "Freireano" é amplamente utilizado, em contexto acadêmico, em relação ao termo "Freiriano".

${ }^{3}$ De acordo com Netto (2009), este se trata do método de análise da realidade, desenvolvido por Karl Marx e Friedrich Engels, com base nas ideias de Friedrich Hegel e Ludwig Feuerbach, no século XVIII, que parte da realidade concreta e histórica da reprodução da vida social na modernidade para produzir os conhecimentos acerca do real, captando e descrevendo sua essência em todos seus movimentos dialéticos na história.
} 
validando elementos particulares em sua totalidade, por meio da dialética marxiana ${ }^{4}$, para propor sua teoria.

A posição de Freire dentro da linhagem da pedagogia crítica é a de um
defensor global da práxis. [...] Aqui eu chamaria a atenção para o
desdobramento do conceito de práxis de Freire, no qual ele entrelaça o
corpo humano em sua dialética materialista da consciência e da práxis. Para
Freire, a realidade era uma totalidade concreta, uma realidade que já é um
todo dialético estruturado e no processo de criação. Como sujeitos, Freire
acredita que podemos sair da prisão do discurso e de seu subjetivismo
correspondente, alterando as condições materiais que nos moldam em
nossa atividade prática. Por meio de um método de análise e de uma
concepção do mundo que envolve uma análise dialética da realidade e uma
unidade dialética com os oprimidos, Freire é capaz de evitar o solipsismo e
o idealismo. Em outras palavras, Freire estava preocupado em interrogar as
relações causais que informam nossa consciência material e volição
subjetiva e intencional. No processo de compreensão do mundo, podemos
aprofundar a nossa consciência, precisamente, por meio de nossas ações e
no mundo e sobre o mundo que nos permitem não apenas entender o
nosso posicionamento, mas também para transformar o conjunto das
relações sociais que constituem o personagem contraditório da nossa
existência. Freire se comprometeu a libertar a nós mesmos e aos outros das
relações ligadas às contradições dialéticas da vida cotidiana. Seu trabalho
estava, portanto, ligado à concepção negativa de Marx sobre a ideologia -
às ações e símbolos que são realmente apenas parciais e fragmentados e,
portanto, distorcidos. Aqui Freire nos exorta a não libertar as pessoas de
suas cadeias, mas a prepará-las para se libertarem através de uma práxis
dialógica ligada a uma dialética materialista da consciência [...]. (MCLAREN,
2020, p. 18).

De fato, Freire elabora uma proposta pedagógica que intenciona, no plano mais geral, produzir uma mudança qualitativa de consciência nos oprimidos. Porém, um aspecto que costuma se perder em alguns debates acerca dessa "mudança de consciência" é a forma como ela se manifesta durante a prática crítica alinhada ao pensamento Freireano. Nessa concepção, a consciência não é ahistórica, ou seja, não é um "estado subjetivo" em que os sujeitos se encontram. Uma consequência dessa determinação é o fato de que a mudança de consciência objetivada na pedagogia Freireana não será, em condições nenhumas, mensurada a partir de uma manifestação verbal ou escrita, esta só será passível de verificação através do movimento histórico, ou seja, a partir da práxis. Assim, a consciência crítica em Freire é uma virtude concreta, é uma mediação dialética entre objetividade e

\footnotetext{
4 José Paulo Netto (2009, p. 675) cita um texto de Marx, o qual diz: "Meu método dialético, por seu fundamento, difere do método hegeliano, sendo a ele inteiramente oposto. Para Hegel, o processo do pensamento [...] é o criador do real, e o real é apenas sua manifestação externa. Para mim, ao contrário, o ideal não é mais do que o material transposto para a cabeça do ser humano e por ela interpretado.".
}

Ideação. Revista do Centro de Educação, Letras e Saúde. v. 23, n², 2021. e-ISSN: 1982-3010. 
subjetividade que movimenta sujeito, em seu sentido coletivo, e objeto em direção de sua unidade dialética, ou seja, para uma racionalização das relações sociais históricas. Essa é uma característica que se explicita a medida que suas referências e inspirações vão sendo identificadas e categorizadas.

A principal característica em comum entre as referências que Freire usa em Pedagogia do Oprimido é a do olhar crítico que se emprega sobre o desenvolvimento da modernidade. Sendo por meio dessa crítica que se organizam os movimentos revolucionários, pois, alguns desses intelectuais, lidos pelo educador, também atuaram como dirigentes de movimentos revolucionários no decorrer do século XX. Portanto, a obra de Freire, bem como sua categoria diálogo, não poderia deixar de ser constituída por essa lógica crítica e por essa essência revolucionária.

Também no que toca à teoria social de Marx, a questão do método se apresenta como um nó de problemas. $E$, neste caso, problemas que não se devem apenas a razões de natureza teórica e/ou filosófica: devem-se igualmente a razões ideopolíticas - na medida em que a teoria social de Marx vincula-se a um projeto revolucionário, a análise e a crítica da sua concepção teórico-metodológica (e não só) estiveram sempre condicionadas às reações que tal projeto despertou e continua despertando. Durante o século XX, nas chamadas sociedades democráticas, ninguém teve seus direitos civis ou políticos limitados por ser durkheimiano ou weberiano - mas milhares de homens e mulheres, cientistas sociais ou não, foram perseguidos, presos, torturados, desterrados e até mesmo assassinados por serem marxistas. (NETTO, 2009, p. 668-669).

É caracterizando sua teoria no campo revolucionário, por meio de sua prática pedagógica, que Freire assume seu compromisso com as massas populares. Toda filosofia pedagógica Freireana têm como base uma relação dialética entre liderança revolucionária, ou educador/intelectual, e as massas aprisionadas nas estruturas materiais de dominação do capital. Assim, Freire (2019, p. 118, tradução minha5), citando um trecho escrito por Mao Zedong em 1944, caracteriza como essa relação deve se desenvolver em sua forma dialógica.

\footnotetext{
5 Transcrição do trecho original: "Pour établir une liaison avec les masses, nous devons conformer à leurs désirs. Dans tout travail pour les masses, nous devons partir de leurs besoins, et non de nos propres désirs, si louables soient-ils. II arrive souvent que les masses aient objetivement besoin de telles ou telles transformations, mais que subjetivement, elles ne soient conscients de ce besoin, qu'elles n'aient ni la volonté ni le désir de les réaliser; dans ce cas, nous devons attendre avec patience; c'est seulement lorsque, à la suite de notre travail, les masses seront, dans leurs majorité conscientes de la nécessité de ces transformations, lorsqu'elles auront la volonté et le désir de les faire aboutir qu'on pourra les realiser; sinon, l'on risque de se couper des masses. [...] Deux principies doivent nous guider: premiérement, les besoins réels des masses et non les besoins nés de notre imagination; deuxiément, le désir librement exprimé par le masses, les resolutions qu'elles ont prises elles mêmes et non celles que nous prenons à leur place.".
} 
A fim de estabelecer um vínculo com as massas, devemos nos conformar com seus desejos. Em todo trabalho para as massas, devemos partir de suas necessidades, e não de nossos próprios desejos, por mais louváveis que sejam. Muitas vezes acontece que as massas necessitam objetivamente de determinadas transformações, mas subjetivamente elas não estão cientes dessas necessidades, não a desejam ou ainda não estão determinadas a realizá-las. Neste caso, devemos esperar pacientemente. Só quando, como resultado do nosso trabalho, as massas estão, em sua maioria, conscientes da necessidade dessas transformações e estejam desejosas e determinadas a realizá-las. Caso contrário, corremos o risco de nos isolar das massas. [...] Dois princípios devem nos guiar: primeiro, as necessidades reais das massas e não as necessidades nascidas de nossa imaginação; em segundo lugar, o desejo expresso livremente pelas massas, as resoluções que elas mesmas tomaram e não as que tomamos em seu lugar.

Assim, a proposta pedagógica do autor possui, em essência, um caráter revolucionário. Esta é feita como a negação das estruturas de opressão que estão postas e se faz pela dialética entre teoria ${ }^{6}$ e prática. Nessa proposta, o ensino, em todos os âmbitos (escolar, formal, não-formal e informal), deixa de ser uma preparação para o futuro e passa a ser um momento de construção dialógica do novo, com a participação horizontalizada do intelectual orgânico e das massas oprimidas, ou educador e educando, mediatizados pela realidade. Essa relação entre teoria e prática se traduz, no materialismo histórico e dialético, como a relação entre subjetividade e objetividade e é discutindo essa relação, a qual em algumas práticas se expressa enquanto práxis revolucionária, que Freire (2019, p. 51) aponta - como forma de problematizar a dicotomização negacionista da subjetividade que algumas interpretações podem incutir sobre o marxismo - que "Em Marx, como em nenhum pensador crítico, realista, jamais se encontrará esta dicotomia. O que Marx criticou, e cientificamente destruiu, não foi a subjetividade, mas o subjetivismo, o psicologismo.".

As estruturas de opressão, no âmbito da ação pedagógica, se materializam no que Freire (2019) denomina como "educação bancária", a qual seria aquela ação educativa que busca realizar "depósitos" de conhecimentos nos educandos, sem levar em consideração seus contextos. Assim, dentro dessa lógica educacional, que é opressora, pois desumaniza, educador e educando estão dicotomizados por suas contradições, sendo a partir da

\footnotetext{
${ }^{6}$ É importante destacar que o significado de teoria é diferenciado dentro da sociologia marxiana, a qual Freire estuda e utiliza para o desenvolvimento de sua pedagogia. De acordo com Netto (2009, p. 674, grifo do autor), para Marx "o conhecimento teórico é o conhecimento do objeto tal como ele é em si mesmo, na sua existência real e efetiva, independentemente dos desejos, das aspirações e das representações do pesquisador. A teoria é, para Marx, a reprodução ideal do movimento real do objeto pelo sujeito que pesquisa: pela teoria, o sujeito reproduz em seu pensamento a estrutura e a dinâmica do objeto que pesquisa. E esta reprodução (que constitui propriamente o conhecimento teórico) será tanto mais correta e verdadeira quanto mais fiel o sujeito for ao objeto.".
} 
problematização dialógica dessas contradições que essa dicotomia será superada. Freire ainda vai além e transpassa os limites do campo educacional, ensaiando sua teoria no campo da organização política ao discutir a contradição do revolucionário que busca a revolução através do depósito da palavra da liberdade na consciência dos oprimidos, ou seja, o ser revolucionário que não o é em comunhão com as massas oprimidas, mas o é tentando buscar fazer a revolução para, não com, os oprimidos.

A organização das massas populares em classe é o processo no qual a liderança revolucionária, tão proibida quanto estas, de dizer sua palavra, instaura o aprendizado da pronúncia do mundo, aprendizado verdadeiro, por isto, dialógico. Daí que não possa a liderança dizer sua palavra sozinha, mas com o povo. A liderança que assim não proceda, que insista em impor sua palavra de ordem, não organiza, manipula o povo. Não liberta, nem se liberta, oprime. (FREIRE, 2019, p. 243).

Assim, Freire constrói sua teoria para além do campo pedagógico e, inclusive, critica aqueles militantes que se propõem a construir a mudança a partir de uma lógica antidialógica, negando a importância dos aspectos pedagógicos em sua ação militante. Logo, a ação transformadora, que se desenrola via práxis, deve ser dialógica, deve se apropriar dos elementos pedagógicos para que a Educação Popular se manifeste na materialidade durante todos os momentos do processo de libertação, e não somente após a tomada do poder pelas classes populares ${ }^{7}$. Diante dessa problemática, Freire (2019) critica aqueles que pensam que a Educação Popular só será construída após a tomada do poder, pois, para o autor, estes estão alienados na contradição do revolucionário que deseja fazer a revolução como forma de doar a liberdade às massas oprimidas.

Se os líderes revolucionários de todos os tempos afirmam a necessidade do convencimento das massas oprimidas para que aceitem a luta pela libertação - o que de resto é óbvio -, reconhecem implicitamente o sentido pedagógico desta luta. Muitos, porém, talvez por preconceitos naturais e explicáveis contra a pedagogia, terminam usando, na sua ação, métodos que são empregados na educação que serve ao opressor. Negam a ação pedagógica no processo de libertação, mas usam a propaganda para convencer... (FREIRE, 2019, p. 75).

\footnotetext{
${ }^{7}$ Para Freire (2019), a tomada do poder pelas classes populares, em sua forma e conteúdo autêntico, só se dará através de processos dialógicos. Portanto, as revoluções que eventualmente ocorram como uma forma de doação da liberdade para os dominados não serão autênticas, o que acarretará em uma não superação das contradições residuais da sociedade anterior. Ainda, para o autor, é natural que essas contradições sobrevivam após a ruptura revolucionária, sendo nesse sentido que o autor defende que a Educação Popular deve ser pautada e construída na nova sociedade como uma forma de constituir o processo de superação dessas contradições.
} 
Por fim, a pedagogia Freireana, bem como a categoria diálogo, não teme a dimensão prática, pois ela se baseia na relação entre prática e teoria. O diálogo se faz tanto no campo subjetivo como no objetivo e, ainda, sempre na objetivação da humanização dos oprimidos, pois, a pedagogia de Freire é a pedagogia dos oprimidos.

\section{A DIALOGICIDADE EM FREIRE}

A pedagogia Freireana têm como base do seu quefazer categorias como contextualização, problematização e dialogicidade. Estas, por se constituírem a partir de uma concepção dialética de história, não funcionam em suas formas dicotomizadas. Assim, não há problematização sem diálogo, pois a problematização se faz a partir da contextualização da materialidade dos sujeitos que, por sua vez, é construída acessando os contextos em uma lógica dialógica.

Portanto, o diálogo, genuinamente Freireano, se expressa em uma forma mais profunda que o simples ato do diálogo vocal entre sujeitos em uma situação de ensino. Este se inicia no ato da investigação dos contextos dos oprimidos, uma relação dialética entre conteúdos, na qual o educador, intelectual ou liderança revolucionária inaugura a dialogicidade ao superar a contradição que o separa das massas populares e se dá conta de que não é o portador da palavra libertadora, reconhecendo que precisa construir essa palavra com e não para o povo.

Daí que, para esta concepção como prática da liberdade, a sua dialogicidade comece, não quando o educador-educando se encontra com os educando-educadores em uma situação pedagógica, mas antes, quando aquele se pergunta em torno do que vai dialogar com estes. Esta inquietação em torno do conteúdo do diálogo e a inquietação em torno do conteúdo programático da educação. Para o educador-bancário, na sua antidialogicidade, a pergunta, obviamente, não é a propósito do conteúdo do diálogo, que para ele não existe, mas a respeito do programa sobre o qual dissertará a seus alunos. E a esta pergunta responderá ele mesmo, organizando seu programa. (FREIRE; 2019, p. 115-116).

Essa é a essência da categoria diálogo na filosofia pedagógica de Paulo Freire, uma comunhão dialética entre a análise crítica $^{8}$ sobre a materialidade pelo intelectual e a

\footnotetext{
${ }^{8}$ O ser crítico, ou concepção crítica, no campo teórico em questão, se expressa na forma lógica pela qual o olhar sobre o real é construído. Uma leitura de mundo que busca, a partir de incongruências e contradições, Ideação. Revista do Centro de Educação, Letras e Saúde. v. 23, n², 2021. e-ISSN: 1982-3010.
} 
vocação ontológica dos Condenados da Terra para a liberdade. Ou seja, o ser social sempre está em busca de sua humanização, negada violentamente pela lógica da exploração do trabalho, porém não a busca objetivamente, isto porque suas contradições, oriundas da introjeção da consciência opressora na consciência dos oprimidos, não os permitem a unidade. É importante destacar que essa introjeção de consciência se configura como uma manifestação concreta, ou seja, uma prática social pautada na ideologia dominante e profundamente contraditória em relação aos interesses materiais da classe trabalhadora.

Pois, o que Freire $(1992,1996,2001,2015,2019)$ propõe é uma pedagogia que tome como ponto de partida essas contradições, as quais se estabelecem no choque entre materialidade e ideologia dos sujeitos que se encontram presos na lógica da opressão. Esses elementos, levantados durante a Investigação Temática $^{9}$, devem ser problematizados de maneira que, em uma lógica pedagógica comprometida politicamente com a humanização, tal processo não teria como se dar sem a dialogicidade. A problematização da realidade é dialógica por uma série de aspectos, como: a dialogicidade já se iniciou a partir da investigação dos contextos dos indivíduos para a construção dos conteúdos, ao deslocar a pergunta "o que ensinar?" do individualismo do educador para a realidade do educando; ao problematizar a realidade, bem como a representação de realidade dos sujeitos, estes abandonam sua passividade, sua posição de espectadores, e passam a atuar como sujeitos ativos da construção do conhecimento em uma relação dialógica entre educador e educando, mediatizados pela realidade; a problematização, genuinamente conectada à realidade e compromissada com a humanização, leva à ação sobre a realidade desvelada que é, em sua gênese, coletiva e, por consequência, dialógica. Portanto, a problematização humanizadora, em seu sentido epistemológico, e a dialogicidade Freireana nunca serão observadas em formas dicotomizadas, pois uma depende da outra para existir, sendo esta uma relação dialética.

Tais características nessa categoria teórica acabam por explicitar sua essência revolucionária, pois um diálogo desenvolvido nesse sentido, em uma realidade violentamente opressora, certamente causará uma resposta dos grupos envolvidos. Essa

estabelecer a corrosão do que está posto enquanto conhecimento. Esse processo também se aplica acerca da crítica produzida, construindo o novo, a verdade, a partir da crítica de uma crítica que é crítica.

${ }^{9}$ Investigação Temática é a forma como Freire propõe para que se desenvolva uma captação da essência material em choque com a representação do real fundante do mundo vivido dos educandos. De acordo com Freire (2019), esse choque entre essência e representação externaliza a contradição vigente nas condições de opressão investigadas, a qual constituem como ponto de partida e alicerce de toda a prática pedagógica compromissada com o processo de libertação. 
ação, para Freire (2019), não se desenvolve a parte do processo pedagógico, ou seja, o estudo crítico da realidade se relaciona diretamente com as ações desenvolvidas sobre essa realidade. Isso se traduz, para Gramsci (1999), em uma Filosofia da Práxis, a qual se baseia em um processo contínuo de ação e reflexão, sendo estas dimensões movimentadas em constante correlação. A ação desvela novos elementos da realidade, historiciza os sujeitos, que complementam a reflexão, sendo esta, por sua vez, um guia para as novas ações. Essa práxis, humanizadora na historicidade das massas oprimidas, se desenvolve em uma lógica dialógica, portanto, as ações revolucionárias que derivam desse processo serão, em seus princípios, dialógicas. No trecho abaixo, é explicitada de forma objetiva a impossibilidade da revolução, a qual é humanizadora, sem o caráter dialógico.

[...] se não é possível o diálogo com as massas populares antes da chegada ao poder, porque falta a elas experiência do diálogo, também não lhes é possível chegar ao poder, porque lhes falta igualmente experiência dele. Precisamente porque defendemos uma dinâmica permanente no processo revolucionário, entendemos que é nesta dinâmica, na práxis das massas com a liderança revolucionária, que elas e seus líderes mais representativos aprenderão tanto o diálogo quanto o poder. (FREIRE, 2019, p. 184).

Essa dialogicidade, consequente da comunhão entre educadores e educandos e lideranças revolucionárias e massas populares, não é observada entre antagônicos. Freire $(2019,2015)$ deixa isso bem explícito em vários momentos de suas obras. No trecho abaixo, o autor discute como o diálogo inaugura a pronúncia do mundo no encontro entre os sujeitos, deixando evidente que este momento, o qual se trata de desvelar a realidade de seus mitos por meio da análise crítica, é das massas oprimidas.

O diálogo é este encontro dos homens, mediatizados pelo mundo, para pronunciá-lo, não se esgotando, portanto, na relação eu-tu. Esta é a razão por que não é possível o diálogo entre os que querem a pronúncia do mundo e os que não a querem; entre os que negam aos demais o direito de dizer a palavra e os que se acham negados deste direito. É preciso primeiro que os que assim se encontram negados no direito primordial de dizer a palavra reconquistem esse direito, proibindo que este assalto desumanizante continue. (FREIRE, 2019, p. 109).

Isso porque as elites que dominam necessitam desses mitos para a manutenção da dominação; estes são os pilares de toda a estrutura de exploração no modo de produção capitalista, e sem eles o sistema dificilmente se manterá. Portanto, é natural que esse 
encontro dialógico jamais ocorrerá entre classes antagônicas, entre dominadores e dominados, opressores e oprimidos, capitalistas e trabalhadores.

Já no trecho abaixo, ao caracterizar a práxis autêntica, que é dialógica, e a problematização mediatizada pela materialidade, Freire expõe, dialeticamente, o seu contrário, ou seja, o quefazer antidialógico.

Para dominar, o dominador não tem outro caminho senão negar às massas populares a práxis verdadeira. Negar-lhes o direito de dizer sua palavra, de pensar certo. As massas populares não têm que, autenticamente, ad-mirar o mundo, denunciá-lo, questioná-lo, transformá-lo para a sua humanização, mas adaptar-se à realidade que serve ao dominador. O quefazer deste não pode, por isto mesmo, ser dialógico. Não pode ser um quefazer problematizante dos homens-mundo ou dos homens em suas relações com o mundo e com os homens. No momento em que se fizesse dialógico, problematizante, ou o dominador se haveria convertido aos dominados e já não seria dominador, ou se haveria equivocado. E se, equivocando-se, desenvolvesse um tal quefazer, pagaria caro por seu equívoco. (FREIRE, 2019, p. 170).

Essa práxis inautêntica, falsa, procura impedir a destruição dos mitos, aprofundando a alienação das massas populares para que estas não façam a revolução. Ainda, o autor evidencia a contradição que a classe dominante estaria se permitisse ou executasse a práxis autêntica, se desenvolvesse uma educação dialógica, problematizante e desmistificadora da realidade.

As classes dominantes, para que existam com seus privilégios, precisam que as estruturas de dominação se mantenham. Ainda, pela lógica fundamental do capital, a qual é a acumulação, é preciso que essas estruturas de dominação, de tempos em tempos, se aprofundem. Para tal, o conteúdo central da manutenção estrutural do capitalismo são os mitos acerca da realidade, uma mistificação da materialidade que impede que os dominados visualizem suas correntes, sendo que estes não podem ser desconstruídos, e se forem, novos serão construídos para que a alienação perdure. É a partir dessas relações entre classe dominante e classe dominada, que o autor afirma que as primeiras jamais permitirão a ocorrência de uma educação crítica na sociedade, pois a criticidade, a qual produz o olhar desmistificador sobre a realidade, é o pensamento pelo qual os mitos são destruídos, mitos estes alicerçantes da estrutura de exploração do trabalho. São esses mitos que Freire (2019, p. 188-189) elenca, os quais são observáveis em nossa contemporaneidade.

O mito, por exemplo, de que a ordem opressora é uma ordem de liberdade. De que todos são livres para trabalhar onde queiram. Se não Ihes agrada o Ideação. Revista do Centro de Educação, Letras e Saúde. v. 23, n², 2021. e-ISSN: 1982-3010. 
patrão, podem então deixá-la e procurar outro emprego. O mito de que esta ordem respeita os direitos da pessoa humana e que, portanto, é digna de todo apreço. O mito de que todos, bastando não ser preguiçosos, podem chegar a ser empresários - mais ainda, o mito de que o homem que vende, pelas ruas, gritando: doce de banana e goiaba é um empresário tal qual o dono de uma grande fábrica. O mito do direito de todos à educação, quando o número de brasileiros que chegam às escolas primárias do país e o do que nelas conseguem permanecer é chocantemente irrisório. O mito da igualdade de classe, quando o sabe com quem está falando? é ainda uma pergunta dos nossos dias. O mito do heroísmo das classes opressoras, como mantenedoras da ordem que encarna a civilização ocidental e cristã, Que elas defendem da barbárie materialista. O mito de sua caridade, de sua generosidade, quando o que fazem, enquanto classe, é assistencialismo, que se desdobra no mito da falsa ajuda que, no plano das nações, mereceu segura advertência de João XXIII. O mito de que as elites dominadoras, no reconhecimento de seus deveres, são as promotoras do povo, devendo este, num gesto de gratidão, aceitar a sua palavra e conformar-se com ela. O mito de que a rebelião do povo é um pecado contra Deus. O mito da propriedade privada, como fundamento do desenvolvimento da pessoa humana, desde, porém, que pessoas humanas sejam apenas os opressores. O mito da operosidade dos opressores e o da preguiça e desonestidade dos oprimidos. O mito da inferioridade ontológica destes e o da superioridade daqueles.

“Desta maneira, se, para dividir [as massas populares], é necessário manter o eu dominado "aderido" à realidade opressora, mitificando-a, para o esforço de união, o primeiro passo é a desmistificação da realidade." (FREIRE, 2019, p. 236, grifo do autor). Assim, a desmistificação da realidade se torna elemento de união e, portanto, as classes dominantes desenvolverão seu papel reacionário frente a qualquer práxis científica que vá no sentido da destruição desses mitos. Nessa reação das classes dominantes para a manutenção da dominação, estas se utilizam das ciências, tanto para a compreensão material dos grupos que serão invadidos e dominados como para o fortalecimento teórico e cultural das mistificações sobre a realidade.

Para este fim, os invasores se servem, cada vez mais, das ciências sociais e da tecnologia, como já agora das naturais. É que a invasão, na medida em que é ação cultural, cujo caráter induzido permanece como sua conotação essencial, não pode prescindir do auxílio das ciências e da tecnologia com que os invasores melhor atuam. Para eles se faz indispensável o conhecimento do passado e do presente dos invadidos, através do qual possam determinar as alternativas de seu futuro e, assim, tentar a sua condução no sentido de seus interesses. (FREIRE, 2019, p. 206).

Nesse sentido, ao desenvolver uma síntese das ideias de Marx sobre o trabalho imaterial, ou trabalho intelectual na modernidade, Sedi Hirano (2001) o caracteriza em duas 
categorias. A primeira é o trabalho intelectual técnico-científico, o qual seria aquele tipo de investigação nas ciências que contribui, de forma direta ou indireta, para o desenvolvimento das forças produtivas e que objetiva o aumento de produtividade. O segundo é o trabalho intelectual cultural, o qual é desenvolvido com os objetivos de ocupar o espaço da reflexão como negação de seu sentido crítico em relação a materialidade e construir as bases teóricas sistematizadas de validação da mistificação alienante da realidade. Este segundo é importante dentro da teoria da ação antidialógica de Freire (2019), pois se torna elemento constituinte de todas categorias dentro dessa teoria e é pólo importante da disputa ideológica pelo pensamento dentro da produção intelectual na modernidade.

Para Marx, o trabalho, que produz ideologias e concepções intelectuais imperantes, é determinado pela produção material. Esse tipo de trabalho intelectual constitui uma força legitimadora e mantenedora do sistema político enquanto organização social concreta - real ou imaginária - de dominação. Nas formas sociais que precedem o modo de produção capitalista, esses ideólogos eram membros do estamento eclesiástico e legista, provenientes do terceiro estado, que justificavam o uso da violência por intermédio da doutrina da guerra justa e da teoria do direito natural, como se a desigualdade fosse posta pela natureza na qualidade de atributo de vontade divina. Enquanto o trabalhador intelectual, localizado na superestrutura, produz o valor de uso na espécie social de meio de dominação do capital, o trabalho técnico-científico - uma modalidade de trabalho intelectual - produz o valor de uso como elemento intelectual objetivado que potencializa as forças produtivas do capital. Ele aparece como algo natural, inerente à sociedade, disponível ao capital. Esse trabalho necessário, indiretamente produtivo, que nada custa ao capital, é essencial ao desenvolvimento das forças produtivas. (HIRANO, 2001, p. 15).

Essa dialética constituinte da relação entre classes opressoras e classes oprimidas as torna, desde sua gênese histórica, antagônicas e, portanto, as impossibilita de dialogar. Seus interesses são profundamente opostos, suas práxis se desenvolvem em sentidos de colisão uma com a outra, pois, enquanto uma busca a desumanização para a exploração, a outra quer se humanizar, quer ser mais. Assim, o suposto "diálogo" entre classes antagônicas, o qual sempre se demonstrará como falso, se desenvolverá no sentido da derrota de alguma delas. Se as classes dominantes forem vitoriosas em suas táticas, os dominados perderão seus meios de vida, se o contrário ocorrer, os dominadores perderão seus privilégios e seu poder sobre a maioria da população, deixando de serem dominadores, ou opressores. É nessa linha de pensamento que Freire diz "Sublinhemos mais uma vez que este encontro dialógico não se pode verificar entre antagônicos." (2019, p. 174). Esse antagonismo, discutido por Freire, surge da desigualdade social entre privilegiados e despossuídos e, 
portanto, "A distância social existente e característica das relações humanas no grande domínio não permite a dialogação." (FREIRE, 2015, p. 67).

\section{O PARADOXO FALSO ENTRE A DIALOGICIDADE E A VIOLÊNCIA REVOLUCIONÁRIA}

Sempre que os processos de libertação e/ou revolucionários entram no centro dos debates, a questão da violência e da perda de vidas ganha grande destaque e, em uma boa parcela das discussões, se torna central. De fato essa é uma problemática constante e relevante em qualquer elaboração de processos revolucionários, ainda mais se considerarmos os que derivam de processos históricos de emancipação conscientizante das classes populares, as quais não possuem os meios materiais de realizar o embate físico com seus dominadores em um certo pé de igualdade. Um observador, principalmente aquele que está posicionado de forma externa ao momento histórico em questão, vai, inevitavelmente, colocar como central e determinante a problemática de uma expressiva perda de vidas dentro de um processo revolucionário que se desenrole para o embate físico entre oprimidos e opressores, pelos mais variados motivos, como: este ainda está imerso nos mitos sobre a modernidade, citados anteriormente; acredita que os oprimidos possuem a legitimidade em reivindicar mais direitos mas, por razões, até mesmo, nobres, pensa que o caminho da não violência é o melhor e pode produzir resultados; sente pelas vidas perdidas, dadas as condições de profunda desvantagens materiais que aqueles que exigem a liberdade estão. Porém, há uma outra problemática que não está sendo considerada nesse tipo de debate, a qual é "de que outra forma o processo de dominação, que é necrófilo, poderia ser cessado? A classe dominante em algum momento histórico já abriu mão de seus privilégios para que os Condenados da Terra pudessem ter uma vida digna?"

Hoje, no século maravilhoso dos espetaculares avanços científicos e tecnológicos, a humanidade ainda amarga problemas sociais, os quais muitos pensam serem coisas do passado, como a fome, o desemprego e o analfabetismo. Só no Brasil, a partir de medições do Instituto Brasileiro de Geografia e Estatísticas (IBGE) realizadas em 2013, quase 6 milhões de brasileiros passavam fome (FELLET, 2019; PINHATA, 2019), e esse cenário de fome só se agrava com a pandemia do covid-19 (FREITAS; PENA, 2020). Ainda, o analfabetismo é um problema presente e crescente na realidade brasileira, sendo que 11,5 milhões de brasileiros com mais de 15 anos ainda não sabiam ler e escrever em 2020 (SOUZA; ANACHE; MACIEL, 
2020). Para o desemprego, uma humilhação carregada por quase 13 milhões de trabalhadores brasileiros, mais os 29 milhões jogados na informalidade sem garantias básicas em trabalhos precarizados, o cenário é cada vez pior, segundo dados recentes do IBGE (VASCONCELOS; SARAIVA, 2020). Todos esses indicadores, que segundo os autores citados estão se aprofundando na piora, demonstram uma realidade de desigualdade e exploração que se mantém como regra no desenvolvimento da modernidade, e se computarmos mais dados dessa natureza, o que ficaria demasiadamente extenso para os propósitos deste ensaio, perceberíamos que não há movimentação no sentido da melhora das condições de vida dos mais pobres.

Em uma realidade material profundamente violenta seria, na melhor das hipóteses, ingênuo idealizar um processo de emancipação das massas populares em uma forma não violenta. Na pior das hipóteses, essa idealização estaria alinhada aos interesses de manutenção das estruturas de exploração do capital. É dentro desse mito que Losurdo (2012), a partir de uma investigação acerca das dialéticas de dominação que ocorrem no âmbito das relações internacionais, começa a expor a contradição, em relação a materialidade, da ideologia da não violência, pois, segundo o autor, esta serve à preservação da exploração do ser humano pelo trabalho. Ainda, em vários exemplos que o autor utiliza em sua obra, estão caracterizadas relações de exploração colonial que dependem, de forma determinante, da ideologia da não violência para que a balança de transferência da riqueza socialmente produzida sempre esteja a favor das potências centrais do capitalismo, numa forma e conteúdo que dão as bases para a conservação da dialética da dependência ${ }^{10}$ (MARINI, 2000).

Freire, sendo um autor autenticamente revolucionário, trabalha sua teoria pedagógica no sentido da emancipação popular, reconhecendo e captando uma essência social que é, desde sua gênese, violenta. Portanto, para um intelectual crítico e dialético como Freire, reconhecer essa realidade violenta e estabelecer um compromisso político com a emancipação daqueles que mais sofrem na pele essa violência, demanda também considerar o caráter violento que esse processo de libertação configurará. Nesse sentido, o autor não deixou de refletir em suas obras sobre essa problemática.

\footnotetext{
${ }^{10}$ De acordo com Ruy Mauro Marini, em sua obra intitulada Dialética da Dependência, há um sistema global de espoliação entre as nações no mundo. Sendo esta realizada através da superexploração do trabalho da mão de obra nos países de capitalismo periférico, de forma a transferir a riqueza socialmente produzida aos países de capitalismo central. Essa lógica joga os povos pobres e oprimidos do mundo em direção ao aprofundamento da miséria e da tragédia social com o objetivo de realizar a manutenção e aprofundamento do acúmulo de capital, localizados na centralidade do sistema.
} 
[...] A situação de opressão em que se formam [os oprimidos], em que realizam sua existência, os constitui nesta dualidade, na qual se encontram proibidos de ser. Basta, porém, que homens estejam sendo proibidos de ser mais para que a situação objetiva em que tal proibição se verifica seja, em si mesma, uma violência. Violência real, não importa que, muitas vezes, adocicada pela falsa generosidade a que nos referimos, porque fere a ontológica e histórica vocação dos homens - a do ser mais. (FREIRE, 2019, p. 57-58)

No trecho acima, extraído do capítulo primeiro de Pedagogia do Oprimido, o autor discute a essência da vida material dos sujeitos em situação de dominação, deixando explícita a ideia de que essas relações, que proíbem os indivíduos de terem uma vida digna, com alfabetização, comida, moradia e comunicação, são a verdadeira violência ${ }^{11}$. Assim, as massas populares se constituem em uma realidade violenta e, portanto, são incapazes de inaugurar a violência de forma objetiva.

Daí que, estabelecida a relação opressora, esteja inaugurada a violência, que jamais foi até hoje, na história, deflagrada pelos oprimidos. Como poderiam os oprimidos dar início à violência, se eles são o resultado de uma violência? Como poderiam ser os promotores de algo que, ao instaurar-se objetivamente, os constitui? Não haveria oprimidos, se não houvesse uma relação de violência que os conforma como violentados, numa situação objetiva de opressão. Inauguram a violência os que oprimem, os que exploram, os que não se reconhecem nos outros; não os oprimidos, os explorados, os que não são reconhecidos pelos que os oprimem como outro. Inauguram o desamor, não os desamados, mas os que não amam, porque apenas se amam. Os que inauguram o terror não são os débeis, que a ele são submetidos, mas os violentos que, com seu poder, criam a situação concreta em que se geram os demitidos da vida, os esfarrapados do mundo. Quem inaugura a tirania não são os tiranizados, mas os tiranos. Quem inaugura o ódio não são os odiados, mas os que primeiro odiaram. Quem inaugura a negação dos homens não são os que tiveram a sua humanidade negada, mas as que a negaram, negando também a sua. Quem inaugura a força não são os que se tornaram fracos sob a robustez dos fortes, mas os fortes que os debilitaram. (FREIRE, 2019, p. 58-59)

\footnotetext{
${ }^{11}$ Ademais, Freire (2015, p. 62), com base nas obras de Frantz Fanon, aponta que "Toda relação de dominação, de exploração, de opressão já é, em si, violenta. [...] De modo geral, porém, quando o oprimido legitimamente se levanta contra o opressor, em quem identifica a opressão, é a ele que se chama de violento, de bárbaro, de desumano, de frio. É que, entre os incontáveis direitos que se admite a si, a consciência dominadora tem mais estes: o de definir a violência. O de caracterizá-la. O de localizá-la. E se este direito lhe assiste, com exclusividade, não será nela mesma que irá encontrar a violência. Não será a si própria que chamará de violenta. Na verdade, a violência do oprimido, ademais de ser mera resposta em que revela o intento de recuperar sua humanidade, é, no fundo, ainda, a lição que recebeu do opressor. Com ele, desde cedo, como salienta Fanon, é que o oprimido aprende a torturar. Com uma sutil diferença neste aprendizado - o opressor aprende a torturar, torturando o oprimido. O oprimido, sendo torturado pelo opressor.".
} 
Desse modo, a hipocrisia do discurso da não violência é, de forma explícita, inaugurada quando as massas populares se engajam na sua vocação ontológica, que o autor denomina de ser mais. Este ser mais é a vontade de classe de ser livre, livre da escravidão assalariada, da ignorância imposta, da fome planejada, da ociosidade miserável no exército de mão de obra de reserva que serve como barganha para precarização, da morte pela falta de remédios que lotam as prateleiras das farmácias, da doença ocasionada da falta de esgoto e água potável, um bem comum de todos os Povos da Terra, do encarceramento em massa de brasileiros que tiveram o "infortúnio" de nascerem pobres e negros, do subdesenvolvimento em geral e de tantas outras formas de escravidão criadas pelo capitalismo. Diante de toda essa materialidade, que só pode ser reconhecida em sua totalidade, o diálogo desvelador, proposto por Freire, paradoxalmente, culminaria na violência, mas não uma violência sádica e vazia, uma violência humanizadora e capaz de inaugurar o autêntico amor humanístico.

Para os opressores, porém, na hipocrisia de sua generosidade, são sempre
os oprimidos, que eles jamais obviamente chamam de oprimidos, mas,
conforme me situem, interna ou externamente, de essa gente ou de essa
massa cega e invejosa, ou de selvagens, ou de nativos, ou de subversivos,
são sempre os oprimidos os que desamam. São sempre eles os violentos, os
bárbaros os malvados, os ferozes, quando reagem à, violência dos
opressores. Na verdade, porém, por paradoxal que possa parecer, na
resposta dos oprimidos à violência dos opressores é que vamos encontrar o
gesto de amor. Consciente ou inconscientemente, o ato de rebelião dos
oprimidos, que é sempre tão ou quase tão violento quanto a violência que
os cria, este ato dos oprimidos, sim, pode inaugurar o amor. (FREIRE, 2019,
p. 59).

$\mathrm{O}$ ato de rebelião dos oprimidos é o encontro dialógico entre as massas, este encontro se manifesta a partir da comunhão entre intelectual e massas populares, ou educadores e educandos. O diálogo autêntico é o que dá início ao processo de práxis e o continua a movimentar, o qual sendo genuíno e revolucionário caminhará na direção da transformação da realidade. Nesse sentido, se a produção de conhecimento for direcionada pela práxis autêntica, construída dialogicamente, este será o desvelador da realidade que, se verdadeiro, inevitavelmente, mobilizará a ação revolucionária. Esse processo, profundamente dialógico, se faz crítico da materialidade e essa crítica, quando em comunhão com o povo, é a desmistificadora dos mitos sobre a realidade moderna. Isso, para as massas populares dominadas, se constitui como uma impossibilidade à passividade objetiva. Ao se reconhecer criticamente na condição de objeto, de um não ser humano, o 
sujeito oprimido caminhará em direção ao otimismo crítico, o qual demandará, obrigatoriamente, a ação.

Aí é que a posição anterior de autodesvalia, de inferioridade, característica da alienação, que amortece o ânimo criador dessas sociedades e as impulsiona sempre às imitações, começa a ser substituída por uma outra, de autoconfiança. E os esquemas e as receitas antes simplesmente importados, passam a ser substituídos por projetos, planos, resultantes de estudos sérios e profundos da realidade. E a sociedade passa assim, aos poucos, a se conhecer. Renuncia à velha postura de objeto e vai assumindo a de sujeito. Por isso, a desesperança e o pessimismo anteriores, em torno de seu presente e de seu futuro, como também aquele otimismo ingênuo, se substituem por otimismo crítico. Por esperança, repita-se. (FREIRE, 2015, p. 51).

O que o autor discute como ação revolucionária não parte de uma perspectiva ingênua, algo que o próprio Freire denomina por otimismo ingênuo. Enquanto intelectual público, revolucionário e popular, Freire entende que a ação de transformação demanda o diálogo, tal como propõe enquanto base teórica de sua pedagogia, e que só é observado entre massas populares e suas lideranças. O diálogo é ocorrência da unidade de diversidade que representa a conscientização das massas, pois estas, em comunhão na luta pela liberdade, negam a forma como os opressores concebem a sociedade, desejam uma que seja humanizadora e não exploradora e, portanto, seria uma contradição profunda não o fazer em sua forma dialógica.

Não sendo um autor que propõe ideias de uma dimensão teoricamente ingênua, Freire aponta alguns exemplos do que seria uma comunhão dialógica das massas, destacando o papel de intelectuais como Ernesto Che Guevara na revolução Cubana.

É impressionante [...] um trecho do relato em que Guevara se refere à sua presença, não apenas como guerrilheiro, mas como médico, numa comunidade camponesa de Sierra Maestra. Ali (diz ele) começou a fazer-se carne em nós a consciência da necessidade de uma mudança definitiva na vida do povo. A idéia da Reforma Agrária se fez nítida e a comunhão com o povo deixou de ser teoria para converter-se em parte definitiva de nosso ser. A guerrilha e o campesinato, continuam, se iam fundindo numa só massa, sem que ninguém possa dizer em que momento se fez intimamente verídico o proclamado e fomos parte do campesinato. Só sei (diz ainda Guevara), no que a mim respeita, que aquelas consultas aos camponeses da Sierra converteram a decisão espontânea e algo lírica em uma força de distinto valor e mais serena. Nunca suspeitaram (conclui com humildade) aqueles sofridos e leais povoadores da Sierra Maestra, o papel que desempenharam como forjadores de nossa ideologia revolucionária. (FREIRE, 2019, p. 231). 
Freire reconhece na ação revolucionária do guerrilheiro argentino a práxis autêntica, a qual só é possível em uma situação de unidade dialógica entre intelectual e massas populares. Outro aspecto importante que pode ser destacado nesse trecho é a forma em que Guevara desenvolve sua ação revolucionária, intercalando momentos de luta guerrilheira e assistência social médica com a população campesina de Sierra Maestra, sendo esta em um sentido investigativo sobre a realidade das massas populares. Este relato pode ser compreendido como um encontro dialógico entre conteúdos, os estudos e visões de mundo de Guevara e as contradições materiais do campesinato, caracterizando, dadas as certas medidas, uma incipiência de Investigação Temática. Essa investigação, mesmo que realizada de forma pouco sistematizada, se assemelha muito com o que Freire (2019) propõe enquanto pressupostos teórico-metodológicos para a captação da essência material dos educandos e caracterização das contradições, ou seja, a Investigação Temática.

Para Freire (2019), esse método de investigação da realidade só pode ser desenvolvido a partir de alguns pré-requisitos teórico-metodológicos, os quais são observáveis na ação de Guevara, como: a superação da contradição educador-educando, ou intelectual-massas, que ocasionará na comunhão dialógica entre estes; o desenvolvimento de uma práxis autêntica mediada pela essência material da vida das massas oprimidas; o encontro dialógico entre conteúdos, estudos e visões de mundo do intelectual e o mundo vivido dos oprimidos, de forma mediada pela materialidade histórica do povo; o compromisso com a liberdade, sempre objetivando o ser mais. Esses elementos são todos observáveis no relato sobre a ação de Guevara e, ainda mais, em seu diário, considerado integralmente, o qual relata sua presença entre 1955 e 1959 em Sierra Maestra (GUEVARA, 1965).

Por mais paradoxal que possa parecer, a ação revolucionária, questionadora e transformadora da realidade no sentido da humanização, é o genuíno diálogo. Obviamente que outras formas de diálogo são possíveis, como a que os educadores desenvolvem com seus educandos em sala de aula ou quando um dirigente sindical abandona suas certezas e começa a construir a luta a partir dos olhos de seus colegas operários, tendo como a real base de sua ação dirigente o chão da fábrica. Porém, diálogos como estes, se constituídos numa relação verdadeiramente horizontal e amorosa entre massas populares e suas lideranças, levarão a um questionamento crítico sobre a realidade, sobre os mitos impostos, o qual será um questionamento objetivo. O sujeito oprimido que se encontra na 
transitividade da consciência fanática para a crítica (Freire, 2015) não limitará seus questionamentos somente ao campo subjetivo, ao captar a essência material em que vive desejará, se em situação de opressão, transformar essa essência.

Como demonstrado neste ensaio, um questionamento crítico, que vá na direção da transformação social, da justiça para os Condenados da Terra, enfrentará o reacionarismo dos que se beneficiam das estruturas de exploração. Portanto, essa reação de violência dos que se acomodaram em privilégios será o verdadeiro antidiálogo, não a reação violenta dos oprimidos que respondem ao seu silenciamento na pronúncia da palavra de liberdade. Nesse sentido, ao tomar a história em suas mãos, as massas populares, que agora são povo, estão, na verdade, amando a vida. A ação revolucionária, inconformada com a ordem necrófila do capitalismo, é o verdadeiro ato de amor, é a verdadeira ação em prol da preservação da vida.

\begin{abstract}
A revolução é biófila, é criadora de vida, ainda que, para criá-la, seja obrigada a deter vidas que proíbem a vida.Não há vida sem morte, como não há morte sem vida, mas há também uma morte em vida. $E$ a morte em vida é exatamente a vida proibida de ser vida.Acreditamos não ser necessário sequer usar dados estatísticos para mostrar quanto, no Brasil e na América Latina em geral, são mortos em vida, são sombras de gente, homens, mulheres, meninos, desesperançados e submetidos a uma permanente guerra invisível em que o pouco de vida que lhes resta vai sendo devorada pela tuberculose, pela esquistossomose, pela diarréia infantil, por mil enfermidades da miséria, muitas das quais a alienação chama de doenças tropicais... (FREIRE, 2019, p. 233-234).
\end{abstract}

Por fim, a tarefa de intelectuais, educadores e lideranças revolucionárias, genuinamente comprometidos com a libertação dos oprimidos, não é a de encorajar a violência pois "ela é justificada", mas a de realizar o debate sincero e corajoso com educandos e massas populares. Abandonar o discurso demagogo do diálogo vazio e imobilizante é o principal requisito para iniciarmos a construção de uma práxis corajosa, uma educação que não tenha medo do povo, de falar do poder popular (FREIRE, 2015, 2019). Se o fatalismo for inaugurado pelos educadores, por meio do cerceamento de certos debates pelo medo das ações que eles podem ocasionar, não há como questionar a postura fatalista dos educandos frente a realidade. Algo essencial para Freire, ao longo de toda sua obra, é a coragem para dialogar com o povo, a qual explicita sua essência revolucionária. 


\section{CONSIDERAÇÕES FINAIS}

É comum em espaços onde a corrente de pensamento hegemônica é antagônica ao pensamento Freireano questionar a sua atualidade em nosso espaço e tempo contemporâneo, a partir de argumentos como: o autor desenvolveu sua teoria em um contexto político diferente, no qual a sociedade estava tomada por um "autoritarismo" político, liderado pela ditadura militar; hoje, com o advento das tecnologias, a forma de se aprender é diferente da do tempo em que Freire trabalhou como educador, e por este motivo suas bases epistemológicas estariam ultrapassadas; o pensamento do autor é muito antigo, datando de meio século atrás. O curioso é que nenhuma dessas argumentativas parece se aplicar a teóricos clássicos da educação ou epistemólogos europeus de correntes de pensamentos alinhadas ao que Freire (2019) chama de educação bancária.

Em geral, diversos autores debatem a atualidade do pensamento de Paulo Freire com base em duas linhas de argumentação: a primeira com foco nas potencialidades que a pedagogia Freireana possui para a aprendizagem crítica sobre questões contemporâneas regionais ou globais; a segunda com foco no seu legado enquanto intelectual relevante e educador, o qual se baseia em diversos campos de pesquisa que se constituíram e projetos de reformas educacionais ocorrentes na história. Essas duas linhas, apesar de profundamente relevantes para a disputa teórica pelo pensamento crítico, deixam de lado uma característica central do intelectual pernambucano, o materialismo histórico e dialético.

Paulo Freire constrói sua caminhada teórica e prática por meio de uma captação da essência material da sociedade, uma concepção materialista e dialética acerca do real. Portanto, sua teoria, de forma alguma, se dissocia da prática, seu pensamento não pode ser analisado somente a partir de um conjunto de ideias, mas sim a partir do confronto com a materialidade. O autor encontra, em sua análise, uma realidade profundamente opressora, baseada em elementos que organizam a sociedade dentro de uma lógica de exploração de muitos e acúmulo das riquezas por poucos. Essa realidade não se modificou, pelo contrário, a exploração foi aprofundada.

Hoje, na terceira década do século XXI, podemos observar o aumento da desigualdade, com o aumento da riqueza dos donos do mundo, o ressurgimento de ideários fascistas e, no Brasil, o desmonte de uma série de garantias sociais conquistadas pela luta popular na constituinte de 1988. Desse modo, não há como afirmar, a não ser a partir de uma alienação profunda, que há liberdade para a maioria da população do mundo, liberdade Ideação. Revista do Centro de Educação, Letras e Saúde. v. 23, n², 2021. e-ISSN: 1982-3010. 
essa que é objetivo central da pedagogia Freireana. Portanto, este é um autor que será atual em qualquer contexto em que existir os que comem muito e os que nada comem. Freire é um autor que se coloca, em diversos momentos de seu pensamento, para além da pedagogia, na teoria da organização política, ou seja, um estrategista da revolução socialista, libertadora e popular, e, por uma questão de materialidade, só deixará de ser atual quando os territórios do mundo forem livres para todos os seres humanos.

\section{REFERÊNCIAS}

FELLET. J. Os dados que contradizem afirmação de Bolsonaro de que não há fome no Brasil. $B B C \quad N e w s / B r a s i l . \quad$ São Paulo, 2019. Disponível em: <https://www.bbc.com/portuguese/brasil-49039151>. Acesso em: 29 de set. 2020.

FREIRE, P. Pedagogia da esperança: um reencontro com a pedagogia do oprimido. Rio de Janeiro: Paz e Terra, 1992.

FREIRE, P. Pedagogia da autonomia: saberes necessários à prática educativa. São Paulo: Paz e Terra, 1996.

FREIRE, P. Política e educação: ensaios. São Paulo: Cortez, 2001.

FREIRE,P. Educação como prática da liberdade. Rio de Janeiro: Paz e Terra, 2015.

FREIRE, P. Pedagogia do oprimido. Rio de Janeiro: Paz e Terra, 2019.

FREITAS, M.C.S.; PENA, P.G.L. Fome e pandemia de covid-19 no Brasil. Tessituras: Revista de Antropologia e Arqueologia. v. 8, n. 1, 2020, p. 34-40.

FREITAS, L.A.A.; FREITAS, A.L.C. Freire e Marx, os caminhos da dialética: ação e reflexão para transformação. In: Colóquio Internacional Paulo Freire, 2013, Rio Grande, Atas... Rio Grande: FURG, 2013.

GRAMSCl, A. Cadernos de cárcere: volume 1. Tradução de Carlos Nelson Coutinho. Rio de Janeiro: Civilização Brasileira, 1999.

GUEVARA, E.C. Relatos de la guerra revolucionaria. Buenos Aires: Nueva, 1965.

HIRANO, S. Política e economia como formas de dominação: o trabalho intelectual em Marx. Tempo social. v. 13, n. 2, 2001, p. 1-20.

LOSURDO, D. A não violência: uma história fora do mito. Tradução Carlo Alberto Dastoli. Rio de Janeiro: Revan, 2012. 
LOURENÇO, S.S.; MENDONÇA, V. M. de. A fenomenologia existencial em Paulo Freire: possíveis diálogos. Filosofia e Educação, v. 10, n. 3, 2018, p. 530-547.

MADUREIRA, C.A. $O$ ato de ensinar ciências: limites e possibilidades da prática pedagógica em sua relação com as diferentes concepções de práxis. Dissertação de Mestrado em Educação, Universidade Federal de São Carlos, São Carlos, 2019.

MARINI, R.M. Dialética da dependência. Petrópolis: Vozes, 2000.

MCLAREN, P. Camarada Freire. Ideação, v. 23, n. 1, 2020.

MICHELS, L.B.; VOLPATO, G. Marxismo e fenomenologia nos pensamentos de Paulo Freire. Filosofia e Educação (online), v. 3, n.1, 2011, p. 122-134.

MONTOVANI, H.J. Hegel e Paulo Freire: uma pedagogia crítico-dialética. Existência e Arte, n. 6, 2011, p. 42-56.

NETTO, J.P. Introdução ao método da teoria social. In: Serviço social: direitos e competências profissionais. Brasília: CFESS/ABEPSS, 2009, p. 667-696.

PINHATA, T. Relatório da ONU indica que fome no Brasil, que antes diminuía, voltou a crescer. Justificando: mentes inquietas pensam Direito. São Paulo, 2019. Disponível em: http://www.justificando.com/2019/07/22/relatorio-da-onu-indica-que-fome-no-brasil-queantes-diminuia-voltou-a-crescer/\#contato. Acesso em: 29 de set. 2020.

SILVA, A.F.G. A construção do currículo na perspectiva popular crítica: das falas significativas às práticas contextualizadas. Tese de Doutorado em Educação, Pontifícia Universidade Católica de São Paulo, São Paulo, 2004.

SILVA, A.F.G. A busca do tema gerador na práxis da educação popular. Curitiba: Gráfica Popular, 2007.

SOUZA, A.L.A.; ANACHE, A.A.; MACIEL, C.E. Um estudo social e profissional da plataforma lattes no Brasil. Revista de teorias e práticas educacionais. v. 28, n. 1, 2020, p. 12-19.

VASCONCELOS, G.; SARAIVA, A. Taxa de desemprego sobe e chega a 12,4\% em junho, aponta IBGE. Valor econômico/Brasil. São Paulo, 2020. Disponível em: $<$ https://valor.globo.com/brasil/noticia/2020/07/23/taxa-de-desemprego-sobe-e-chega-a124percent-em-junho-aponta-ibge.ghtml>. Acesso em: 15 out. 2020.

Recebido em 19 de dezembro de 2020.

Aprovado em 07 de junho de 2021.

(1) (1)(2) 